\title{
Cord blood transplantation: can we make it better?
}

\section{Leland Metheny, Paolo Caimi and Marcos de Lima*}

Stem Cell Transplantation Program, University Hospitals Case Medical Center, Case Western Reserve University, Cleveland, OH, USA

\section{Edited by:}

Partow Kebriaei, The University of Texas MD Anderson Cancer Center, USA

\section{Reviewed by:}

Peiman Hematti, University of

Wisconsin-Madison, USA

Qaiser Bashir, The University of Texas

MD Anderson Cancer Center, USA

*Correspondence:

Marcos de Lima, Stem Cell

Transplantation Program, University

Hospitals Case Medical Center, Case

Western Reserve University, 11100

Euclid Avenue LKS 5079, Cleveland,

$\mathrm{OH}$ 44106, USA

e-mail: marcos.delima@

uhhospitals.org
Umbilical cord blood is an established source of hematopoietic stem cells for transplantation. It enjoys several advantages over bone marrow or peripheral blood, including increased tolerance for Human Leukocyte Antigen mismatches, decreased incidence of graft-versus-host disease, and easy availability. Unrelated cord blood does have limitations, however, especially in the treatment of adults. In the 24 years since the first umbilical cord blood transplant was performed, significant progress has been made, but delayed hematopoietic engraftment and increased treatment-related mortality remain obstacles to widespread use. Here we summarize the latest results of unrelated cord blood transplants, and review strategies under investigation to improve clinical outcomes.

Keywords: umbilical cord blood transplantation, ex vivo expansion, delayed engraftment, double umbilical cord transplant, mesenchymal stem cells, reduced intensity conditioning

\section{INTRODUCTION}

Since the first sibling human leukocyte antigen (HLA)-matched umbilical cord blood transplant (UCBT) was performed in 1989 by Gluckman and Colleagues on a pediatric patient with Fanconi's anemia, cord blood stem cells have been recognized for their benefits (1). Umbilical cord blood (UCB) hematopoietic stem cells can be procured easily, without risk to the donor, and an appropriate number of stem cells can be stored, tested, and processed for future use (2-4). These advantages make UCB suitable to fill the growing need for suitable grafts for patients with hematologic malignancies or underlying bone marrow or metabolic defects. It is also important to note that a significant population of patients, specifically minority groups, lack a suitable HLA-matched bone marrow, or peripheral stem cell donor, thus UCB offer an important source of allografts for such groups (5). In this review we examined the two decade history of this subset of allogeneic stem cell transplants, and then focused specifically on the major developments for improving and accelerating cord blood engraftment, widely recognized as its' Achilles heel. A comparison of haploidentical and cord blood grafts is beyond the scope of this review.

\section{PEDIATRIC UMBILICAL CORD BLOOD TRANSPLANTATION}

Following the report of the first sibling HLA-matched UCBT, the first pediatric studies showed UCBT present higher rates of primary engraftment failure as well as delayed time to engraftment. Initial studies investigating the impaired engraftment in UCBT focused on HLA matching and the optimum dosage of CD34+ cells or total nucleated cells (TNC). It is important to note that many of these studies were retrospective; almost 20 years passed between the Gluckman's first transplant and the first prospective randomized clinical trial (phase 2). This underscores the continued need for prospective randomized clinical trials, as bias is a much more significant problem in retrospective studies.
Wagner et al. described 44 patients who underwent matched sibling UCBT, mismatched at 0 or 1 HLA locus (6). Day 50 engraftment rate was $85 \%$, while the rate of grade II-IV acute graftversus-host disease (aGVHD) was a very low $3 \%$, with a survival rate at 1.6 years of $72 \%$. However, primary graft failure occurred in $15 \%$ of patients. Subsequently, 22 patients were reported that received either HLA-matched or HLA 1-3 antigen mismatched cord grafts (7). Engraftment at day 50 was $100 \%$, with aGVHD rate of $11 \%$, while 6-month survival rate was $65 \%$. These early studies positioned UCBT as a clear alternative for pediatric patients in need of allogeneic transplantation.

Subsequently, Barker and Coworkers compared 0-3 HLA mismatched UCBT recipients with recipients of unrelated matched bone marrow transplants (BMT). This matched pair analysis suggested that mismatched UCBT led to similar survival than matched BMT, but at expense of longer time to engraftment with similar aGVHD rates (8). Rubinstein et al. performed an analysis of transplants from the New York cord blood bank, and observed that the chances of successful engraftment could be increased with a better HLA-matched cord (9).

Gluckman et al. reported the Eurocord registry experience in 1997, showing that recipients of related UCBT had rates of 1-year survival, grade II-IV aGVHD, and day 60 neutrophil engraftment of 55,18 , and $79 \%$, respectively; recipients of unrelated UCBT had rates of 1-year survival, grade II-IV aGVHD, and neutrophil engraftment at day 60 of 31,32, and $89 \%$ (10). Rocha et al. retrospectively compared outcomes of pediatric UCBT, T cell depleted bone marrow, and non-manipulated BMT. UCB was again associated with delayed neutrophil and platelet engraftment as well as increased early treatment-related mortality (TRM). However, the risk of aGVHD was lower, while the overall risk of relapse was similar among groups. Mortality was greatest in the T cell depleted BMT group (11). 
In another observational, retrospective study, Eapen and Collaborators compared pediatric matched and mismatched UCBT with matched or mismatched unrelated BMT. The authors again pointed to delayed engraftment and increased TRM with UCBT, especially for those receiving low cell doses. However, 5-year leukemia-free survival (LFS) rates were similar between all groups and the risk of relapse was lowest in UCBT with two mismatched alleles (12).

The first prospective multicenter study in pediatric UCBT, published in 2008, enrolled 191 patients with high-risk hematologic malignancies. Cord grafts were matched to at least 3 of 6 HLA loci, and median TNC infused was $3.9 \times 10^{7} \mathrm{c} / \mathrm{kg}$. The conditioning regimen was myeloablative, with $1350 \mathrm{cGy}$ total body irradiation (TBI), cyclophosphamide $\left(60 \mathrm{mg} / \mathrm{m}^{2}\right)$, and equine ATG $(15 \mathrm{mg} / \mathrm{kg})$. Median time to neutrophil and platelet engraftment was 27 and 173 days, respectively. Primary graft failure occurred in $11 \%$ of patients, while rates of grade II-IV aGVHD, relapse, and 2-year OS were 42, 19, and 50\%, respectively (13).

Two subsequent studies emphasized the importance of cell dose on engraftment and TRM. In an observational study of pediatric UCBT, Wagner's group found that among donor-recipient pairs with $\leq 2 / 6$ HLA mismatches at HLA A, B, and DRB1, UCBT consisting of a cell dose of $1.7 \times 10^{5} \mathrm{CD} 34+$ cells $/ \mathrm{kg}$ resulted in improved outcomes (14). Gluckman, Locatelli, and others on behalf of the Eurocord, showed that pediatric leukemia patients receiving a TNC dose above $3.7 \times 10^{7}$ had a higher probability of engraftment and survival $(10,15,16)$, with a median time to neutrophil engraftment of 25 days compared to 35 days for those receiving $<3.7 \times 10^{7} / \mathrm{kg}$.

These studies solidified the role of UCBT as an alternative to traditional forms of transplant. They also clearly defined the importance of HLA matching and cell dose in UCBT. Grafts with more than 3/6 HLA mismatches (low resolution typing for HLA A and $\mathrm{B}$, and high-resolution DRB1 typing) result in significantly higher TRM rates and should be avoided. The importance of "minimum" cell dose was also established, and is an additional complicating factor in adults, as the cell dose threshold is unlikely to be reached with a single UCB unit in this patient population.

\section{ADULT UMBILICAL CORD BLOOD TRANSPLANTATION}

Adult UCBT studies have also been mostly retrospective, and continue to show worse outcomes when compared with those of pediatric populations. The cell doses in these studies have been significantly lower than the "minimum" defined by Wagner, Gluckman and others (10, 14-16).

In 2001, Laughlin and Colleagues retrospectively analyzed the outcomes after adult UCBT following myeloablative conditioning for malignant and non-malignant hematological diseases. The median infused TNC was $1.6 \times 10^{7} / \mathrm{kg}$; all patients had a graft with three or less HLA mismatches. The median time to neutrophil and platelet engraftment was 27 and 99 days, respectively. Graft failure occurred in $10 \%$ of patients, and grade II-IV aGVHD rate was $60 \%$. At 40 months, $26 \%$ of patients were alive. CD $34+$ cell dose was associated with improved event-free survival (EFS) (17). Subsequently, other adult UCBT studies have also observed a high rate of graft failure and delayed engraftment compared to bone marrow or peripheral blood grafts (18-22) (Tables 1 and 2).
Rocha compared the outcomes of 98 UCBT patients reported to the Eurocord with those of 584 patients who received matched bone marrow grafts (intermediate resolution HLA typing for HLA $\mathrm{A}$ and $\mathrm{B}$, and high-resolution typing for HLA-DRB1). Of note, the average TNC dose differed by a factor of 10 between groups: in the UCBT cohort the TNC was $2.3 \times 10^{7} \mathrm{c} / \mathrm{kg}$ compared to $2.9 \times 10^{8} \mathrm{c} / \mathrm{kg}$ for those undergoing BMT. Although the degree of donor-recipient HLA mismatches was higher in the cord blood group (most subjects received 4/6 matched units), aGVHD risk was significantly lower compared to the BMT cohort. Neutrophil engraftment was significantly delayed in the cord blood group, and primary graft failure occurred in $20 \%$ of UCBT patients versus $7 \%$ in the bone marrow group. Nevertheless, overall survival and the rates of TRM, cGVHD, relapse, and LFS were not significantly different between the two groups (23).

In a retrospective analysis using registry databases, Eapen compared 165 UCBT, 888 peripheral blood progenitor cell (PBPC), and 472 BMT recipients. TRM was higher in the umbilical cord group, but LFS was similar across all groups. The rate of aGVHD was lower after UCBT compared to PBPC, while cGVHD was lower in the UCBT compared to $8 / 8$ matched BMT (24). A similar retrospective study by Eapen also demonstrated the importance of HLA C matching in UCBT (25) (Table 3).

Taken in aggregate, these studies indicate that adults receiving single, mismatched UCB grafts have higher early mortality but similar overall survival to that observed in recipients unrelated donor BMT or PBSC. Neutrophil and platelet engraftment is delayed, and a smaller proportion of patients become platelet transfusion independent. Primary graft failure rates are also higher with single UCBT than when using peripheral blood or bone marrow grafts (Table 2). Of note, all comparative studies published to date are retrospective, and there seems to be a significant variation in center outcomes.

\section{REDUCING TRM IN UCBT: REDUCED INTENSITY CONDITIONING, DOUBLE UMBILICAL CORD TRANSPLANTS, AND HLA MATCHING}

Due to high TRM rates, UCBT is often used as a transplant of last resort. Early efforts to reduce TRM focused on reducing conditioning regimen toxicity and increasing UCB cell dose. Most studies available correspond to small prospective trials, usually from a single institution.

Reduced intensity conditioning has reduced early mortality in allogeneic transplants, and has allowed treatment of older and frailer patients (26-34). Barker et al. treated 43 patients with highrisk hematologic malignancies. Two regimens were used: busulfan $(8 \mathrm{mg} / \mathrm{kg})$, fludarabine $\left(200 \mathrm{mg} / \mathrm{m}^{2}\right)$, and of TBI (200 cGy) (BFT) in 21 patients; and cyclophosphamide $(50 \mathrm{mg} / \mathrm{kg})$, fludarabine $\left(200 \mathrm{mg} / \mathrm{m}^{2}\right)$, and TBI (200 cGy) (CFT) in 22 patients. UCB units were matched to at least 4/6 HLA loci. Median time to neutrophil engraftment was 9.5 and 22 days in the CFT and BFT groups, respectively, while sustained engraftment was observed in 94 and $76 \%$ in the CFT and BFT groups. For the whole cohort, 1-year overall survival was $39 \%$ with $21 \%$ relapse rate and $9 \%$ grade IIIV aGVHD (35). This low dose TBI-based regimen is now widely used in the U.S., and retrospective comparisons have suggested it is superior to alkylating-based combinations (36). 
Table 1 | Comparison of multiple UCBT studies, including both pediatric and adult patients and single UCBT and dUCBT.

\begin{tabular}{|c|c|c|c|c|c|c|c|}
\hline Study & Type & $\begin{array}{l}\text { No. } \\
\text { patients }\end{array}$ & Cord information & $\begin{array}{l}\text { Primary } \\
\text { graft } \\
\text { failure }(\%)\end{array}$ & $\begin{array}{l}\text { Time to } \\
\text { neutrophil and } \\
\text { platelet engraftment } \\
\text { (days) }\end{array}$ & $\begin{array}{l}\text { Grade II-IV } \\
\text { aGVHD } \\
(\%)\end{array}$ & Survival \\
\hline Wagner et al. (6) & Pediatric & 44 & $\begin{array}{l}\text { Single cord HLA } \\
\text { identical/HLA-1 } \\
\text { mismatch }\end{array}$ & 15 & Neutrophil $=22$ & 3 & 1.6 year OS $=72 \%$ \\
\hline Wagner et al. (7) & Pediatric & 18 & $\begin{array}{l}\text { Single cord } \\
\text { HLA-matched versus } \\
\text { HLA (1-3) mismatched }\end{array}$ & 0 & $\begin{array}{l}\text { Neutrophil }=24 ; \\
\text { platelet }=54\end{array}$ & 11 & 6 month OS $=65 \%$ \\
\hline Wagner et al. (14) & $\begin{array}{l}\text { Pediatric } \\
\text { retrospective }\end{array}$ & 102 & $\begin{array}{l}\text { Single cord 0-3 HLA } \\
\text { mismatched }\end{array}$ & 5 & $\begin{array}{l}\mathrm{GCSF}(+) \text { neutrophil }=21 \\
\mathrm{GCSF}(-) \text { neutrophil }=31 \\
\text { platelet }(50 \mathrm{k})=86\end{array}$ & 11 & 1 year $\mathrm{OS}=58 \%$ \\
\hline Kurtzberg et al. (13) & Pediatric & 191 & $\begin{array}{l}\text { Single cord 0-3 HLA } \\
\text { mismatched }\end{array}$ & 11 & $\begin{array}{l}\text { Neutrophil = 27; platelet } \\
(50 \mathrm{k})=174\end{array}$ & 19.5 & 2 year $O S=49.5 \%$ \\
\hline Laughlin et al. (17) & Adult & 68 & $\begin{array}{l}\text { Single cord 0-3 HLA } \\
\text { mismatched }\end{array}$ & 7 & $\begin{array}{l}\text { Neutrophil = 27; } \\
\text { platelet }=99\end{array}$ & 60 & 40 month $\mathrm{OS}=27 \%$ \\
\hline Sanz et al. (18) & Adult & 22 & $\begin{array}{l}\text { Single cord 0-3 HLA } \\
\text { mismatched }\end{array}$ & 0 & $\begin{array}{l}\text { Neutrophil }=22 ; \\
\text { platelet }=69\end{array}$ & 73 & 8 month $\mathrm{OS}=54 \%$ \\
\hline Takahashi et al. (20) & Adult & 68 & $\begin{array}{l}\text { Single 0-2 HLA } \\
\text { mismatched }\end{array}$ & 8 & $\begin{array}{l}\text { Neutrophil }=22 ; \\
\text { platelet }=40\end{array}$ & 44 & 2 year $\mathrm{DFS}=74 \%$ \\
\hline Rocha et al. (23) & $\begin{array}{l}\text { Adult } \\
\text { retrospective }\end{array}$ & 98 & $\begin{array}{l}\text { Single cord 0-3 HLA } \\
\text { mismatched }\end{array}$ & 20 & Neutrophil = 26 & 26 & 2 year $\mathrm{OS}=36 \%$ \\
\hline Cornetta et al. (19) & Adult & 34 & $\begin{array}{l}\text { Single cord 0-2 HLA } \\
\text { mismatched }\end{array}$ & 34 & $\begin{array}{l}\text { Neutrophil }=42 \\
\text { platelet }=180\end{array}$ & 34 & $\mathrm{D} 180 \mathrm{OS}=30 \%$ \\
\hline Brunstein et al. (41) & Adult RIC & 110 & $\begin{array}{l}85 \% \text { dUCBT/15\% } \\
\text { single 0-2 HLA } \\
\text { mismatched }\end{array}$ & 6 & $\begin{array}{l}\text { Neutrophil }=22 ; \text { platelet } \\
(50 k)=59\end{array}$ & 59 & 3 year $\mathrm{OS}=26 \%$ \\
\hline Ballen et al. (21) & Adult RIC & 21 & $\begin{array}{l}\text { dUCBT 0-2 HLA } \\
\text { mismatched }\end{array}$ & 9 & $\begin{array}{l}\text { Neutrophil =20; } \\
\text { platelet }=41\end{array}$ & 40 & 2 year $O S=71 \%$ \\
\hline
\end{tabular}

GCSF, granulocyte colony stimulating factor; OS, overall survival; DFS, disease free survival.

Double UCBT (dUCBT) has been proposed as a strategy to increase cell dose and possibly improve outcomes $(37,38)$. Barker and Collaborators treated 22 hematologic malignancy patients with myeloablative conditioning and dUCBT grafts containing a median TNC dose of $3.5 \times 10^{7} / \mathrm{kg}$, matched to at least $4 / 6$ HLA loci. Median time to neutrophil engraftment in this adult cohort (median weight of $73 \mathrm{~kg}$ ) was 23 days. There were no primary or secondary graft failures, while aGVHD II-IV and 1 year DFS rates were 65 and 57\%, respectively (39).

MacMillan and coworkers retrospectively compared outcomes of single versus dUCBT treated at the University of Minnesota. Although cGVHD rates were similar (17 versus 18\%), grade IIIV aGVHD rates were greater in the dUCBT group (58 versus $39 \%, p<0.01)$. dUCBT recipients presented GVHD at earlier time points (day 28 versus 36 ) but had lower 1-year TRM rates (24 versus $39 \%, p=0.02)(40)$.

Brunstein and Colleagues reviewed the results of a non-myeloablative conditioning regimen consisting of fludarabine $\left(200 \mathrm{mg} / \mathrm{m}^{2}\right)$, cyclophosphamide $\left(50 \mathrm{mg} / \mathrm{m}^{2}\right)$, and a single fraction of $200 \mathrm{cGy}$ TBI on 110 patients with high-grade hematologic malignancies (41). TNC dose target was $3.0 \times 10^{7} / \mathrm{kg}$, and patients were to receive a dUCBT if a single unit did not provide that cell dose. Eight-five percent of patients received a dUCBT. TRM rate was $19 \%$ at 180 days and OS was $26 \%$ at 3 years. Relapse rates were higher in the single cord group compared to the dUCBT group (41 versus $30 \%, p=0.07$ ), while aGVHD incidence tended to be higher in the dUCBT cohort (62 versus $41 \%, p=0.09$ ). Primary and secondary graft failure occurred in 6 and 7\% of patients, respectively. Overall, higher rates of TRM were associated with age below 45 years, recipient negative CMV serostatus, use of ATG, high-risk clinical features and recent fungal infection.

Kindwall-Keller conducted a prospective study involving highrisk patients with hematologic malignancies comparing single $(n=27)$ versus dUCBT $(n=23)$. Both patient groups received fludarabine $\left(35 \mathrm{mg} / \mathrm{m}^{2}\right)$, cyclophosphamide $\left(1 \mathrm{~g} / \mathrm{m}^{2}\right)$, horse ATG $(30 \mathrm{mg} / \mathrm{kg})$, and $200 \mathrm{cGy}$ TBI. Single UCB graft had at least $2.5 \times 10^{7} \mathrm{TNC} / \mathrm{kg}$, while dUCBT grafts should provide 
Table 2 | Comparison of graft sources.

\begin{tabular}{|c|c|c|c|c|c|c|}
\hline Study & Type & Groups & $\begin{array}{l}\text { No. } \\
\text { patients }\end{array}$ & $\begin{array}{l}\text { Neutrophil } \\
(\text { ANC }=500) \text { and } \\
\text { platelet engraftment } \\
(20,000)\end{array}$ & $\begin{array}{l}\text { Grade II-IV } \\
\text { aGVHD }\end{array}$ & Survival \\
\hline \multirow[t]{2}{*}{$\begin{array}{l}\text { Hamza et } \\
\text { al. (22) }\end{array}$} & $\begin{array}{l}\text { Adult } \\
\text { retrospective }\end{array}$ & $\begin{array}{l}\text { UCB, at least HLA } \\
3 / 6 \text { matched }\end{array}$ & 28 & Neutrophil= day 29 & $33 \%$ & $\begin{array}{l}\text { EFS day } 100=34 \% ; E F S \\
3 \text { year }=25 \%\end{array}$ \\
\hline & & MUD & 23 & Neutrophil = day 14 & $27 \%$ & $\begin{array}{l}\text { EFS day } 100=78 \% ; E F S \\
3 \text { year }=35 \%\end{array}$ \\
\hline \multirow[t]{3}{*}{$\begin{array}{l}\text { Eapen et } \\
\text { al. (24) }\end{array}$} & $\begin{array}{l}\text { Adult retro- } \\
\text { spective/Cox } \\
\text { regression }\end{array}$ & $\begin{array}{l}\text { UCB at least HLA } \\
4 / 6 \text { matched }\end{array}$ & 165 & $\begin{array}{l}\text { Neutrophil = day } 24, \\
\text { platelet }=\text { day } 52\end{array}$ & $30 \%$ & $\mathrm{LFS}=59 \%$ \\
\hline & & PBPC & 888 & $\begin{array}{l}\text { Neutrophil = day } 14, \\
\text { platelet }=\text { day } 19\end{array}$ & $\begin{array}{l}8 / 8 \text { HLA matched }=48 \% \\
7 / 8 \text { HLA matched }=52 \%\end{array}$ & $\begin{array}{l}\text { 8/8 HLA matched }=57 \% ; \\
7 / 8 \text { HLA matched }=66 \%\end{array}$ \\
\hline & & BM & 472 & $\begin{array}{l}\text { Neutrophil = day } 19, \\
\text { platelet }=\text { day } 28\end{array}$ & $\begin{array}{l}8 / 8 \text { HLA matched }=39 \% \\
7 / 8 \text { HLA matched }=46 \%\end{array}$ & $\begin{array}{l}\text { 8/8 HLA matched }=56 \% ; \\
7 / 8 \text { HLA matched }=57 \%\end{array}$ \\
\hline
\end{tabular}

UCB, umbilical cord blood; MUD, matched unrelated donor; PBPC, peripheral blood progenitor cells; BM, bone marrow.

Table 3 | Retrospective analysis of HLA C typing in UCBT.

\begin{tabular}{|c|c|c|c|c|c|}
\hline Study & Type & Groups & No. patients & $\begin{array}{l}\text { Transplant related } \\
\text { mortality }\end{array}$ & Overall survival \\
\hline \multirow[t]{3}{*}{$\begin{array}{l}\text { Eapen et } \\
\text { al. (25) }\end{array}$} & $\begin{array}{l}\text { Allo pediatric } \\
\text { retrospective/Cox regression }\end{array}$ & $\begin{array}{l}\text { HLA A, B, C, and DRB1 } \\
\text { matched }\end{array}$ & 69 & 3 year TRM = 9\% & 3 year OS $=57 \%$ \\
\hline & & $\begin{array}{l}\text { HLA A, B, and DRB1 matched; } \\
\text { HLA C mismatched }\end{array}$ & 23 & 3 year TRM = 26\% & 3 year OS $=51 \%$ \\
\hline & & $\begin{array}{l}\text { Either HLA A, B, or DRB1 } \\
\text { mismatch + HLA C mismatch }\end{array}$ & 234 & 3 year TRM = $31 \%$ & 3 year $\mathrm{OS}=37 \%$ \\
\hline
\end{tabular}

TRM, treatment-related mortality; OS, overall survival.

a combined $3.0 \times 10^{7} \mathrm{TNC} / \mathrm{kg}$. Each cord was matched at least 4/6 HLA loci to the recipient. Seven patients (26\%) in the single unit group and five patients $(22 \%)$ in the double unit group failed to engraft. The median time to neutrophil engraftment was 25 days in the single cord group and 23 in the double cord group $(p=0.99)$. The median time to platelet engraftment was 39 days in the single cord group and 57 in the double cord group. Relapse rates were significantly lower in the dUCBT group (30 versus $59 \%, p=0.045$ ). There was no significant difference in aGVHD rates between the two groups. Overall survival at 60 months was $39 \%$ in the dUCBT group and $26 \%$ in the single unit group $(p=0.86)(42)$.

Although the controversy surrounding single versus dUCBT in adult patients is far from resolved, a recently completed phase III clinical trial comparing single and double cord transplants in pediatric patients showed no difference in 1 year survival ( 71 versus $65 \%, p=0.13$ ). In addition, increased aGVHD rates were observed after dUCBT (14 versus 23\%, $p=0.03$ ) (43). These results argue against $\mathrm{dUCBT}$ in pediatric patients outside of clinical trials.
Further data continues to be reported on retrospective comparisons of $\mathrm{CB}$ versus other sources of hematopoietic stem cells for transplant. More recent studies incorporate highresolution class I HLA typing for the controls. Brunstein and Collaborators compared the outcomes of patients receiving matched related donor transplants $(n=204)$, MUD $(n=152)$, mismatched unrelated donor $(n=52)$, and 4-6/6 HLA-matched dUCBT $(n=128)$. dUCBT was associated with similar LFS, at the expense of delayed hematopoietic engraftment, with lower aGVHD rates. Interestingly, relapse risk was lower in the dUCBT group, but at the expense of higher rates of early TRM (44).

Many of the above studies stress the importance of both HLA matching and TNC, however, the question arises: which is more important? In 2010, Avery analyzed 84 dUCBT and found no relation to HLA matching and sustained donor engraftment or time to neutrophil engraftment (45). In regards to single UCBT, both Arcese et al. and Laughlin et al. found no correlation with GVHD or survival with HLA disparity $(17,46)$. Thus it would seem that cord selection would be based primarily on TNC dose. However, 
a large retrospective analysis by Barker, focusing on 1061 single unit UCBT, found that patients with 0 HLA mismatches had a lower TRM independent of TNC. Interestingly, the greater HLA mismatch, the greater the importance of TNC was on overall survival. For example, patients with 1-2 HLA mismatch and a TNC $>5.0 \times 10^{7} \mathrm{c} / \mathrm{kg}$ had a TRM of almost half of patients with 1-2 HLA mismatch and a TNC between 2.5 and $4.9 \times 10^{7} \mathrm{c} / \mathrm{kg}$ (47). This study suggests HLA mismatch plays a more important role that previously thought, especially in single UCBT. Current opinion with regard to cord selection recommends screening for grafts with $>2.0 \times 10^{7} \mathrm{c} / \mathrm{kg}$ and 4-6 HLA matches, then grouping cords into $6 / 6,5 / 6$, and 4/6 HLA-matched groups, and finally out of that best matched group, select the graft with the highest TNC (48).

\section{UMBILICAL CORD ENHANCEMENT}

Focus has since shifted to methods of umbilical cord graft enhancement. These endeavors include umbilical cord expansion to increase the transplanted cell dose; methods that increase engraftment; alternative UCB delivery procedures; or co-transplantation with other types of cell grafts. As mentioned previously, due to a much larger body mass, the ratio of CD34+ cells or TNC to kilograms is significantly decreased in adults compared to pediatric patients. UCB expansion techniques attempt to overcome this challenge by increasing cell dose prior to infusion. Alternative delivery methods of UCB attempt to by-pass presumed stem cell trapping and/or decrease transit time to the bone marrow. Most of the studies reported are phase I or II and represent the latest advances in UCBT.

\section{COMBINING HAPLOIDENTICAL HEMATOPOIETIC STEM CELLS WITH UNRELATED CORD BLOOD}

Fernández and Collaborators hypothesized that selected CD34 haploidentical cells, when co-infused with UCB cells, would result in earlier engraftment. Interestingly, in the majority of the cases the haploidentical cells provided early engraftment but were subsequently rejected by the long-term engrafting cord blood cells (49). Recently, Lui and Colleagues expanded on Fernández's observation (50). Forty-five patients with hematologic malignancies underwent RIC (fludarabine, melphalan, and ATG), followed by T cell depleted haploidentical CD34+ cells from a non-maternal donor (CD34+ cell dosage up to $3 \times 10^{6} \mathrm{c} / \mathrm{kg}$ ), and an UCB graft (minimum cell dose of $1 \times 10^{7} \mathrm{c} / \mathrm{kg}$ and at least a 4/6 HLA match). Median time to neutrophil and platelet engraftment was 11 and 19 days, respectively, while aGVHD rate was $25 \%$. TRM at day 100 was $9 \%$, and 1 -year overall survival was $55 \%$.

\section{EX VIVO UMBILICAL CORD EXPANSION}

Shpall et al. employed a liquid culture system to expand a fraction of the UCB unit. Expanded UCB cells were selected for CD34, and after 10 days in liquid culture, TNC was expanded 56-fold, and CD34+ cells, fourfold. The expanded portion was then infused with the unmanipulated UCB. The median CD34+ cell dose was $10.4 \times 10^{4} \mathrm{c} / \mathrm{kg}$. The median time to neutrophil and platelet engraftment was 28 and 106 days respectively. Overall survival was $35 \%$ at 30 months (51). Subsequently, a randomized study at MDACC compared "standard" dUCBT versus one unmanipulated unit co-infused with a $100 \%$ expanded unit using the approach described above. Modifications of the expansion strategy included CD133 selection instead of CD34 (given the possibility of selecting earlier hematopoietic progenitors using CD133), and freezing the unselected cells left after CD133 separation, with reinfusion at the time of transplant (hypothesizing that this cell population could contain engraftment-facilitating cells). This trial, reported in abstract form, did not show an advantage for ex vivo expansion in terms of engraftment or survival (52). It is likely that cytokine-based liquid culture systems, such as the ones used in these expansion methods, push progenitor cells toward a less differentiated stage of maturation, essentially depleting the stem cell potential.

\section{EX VIVO UMBILICAL CORD EXPANSION CO-CULTURED WITH MESENCHYMAL STEM CELLS}

The bone marrow microenvironment is important for the proliferation and differentiation of hematopoietic stem cells (53-58). Mesenchymal stem cells (MSCs) are found in the bone marrow and give rise to bone marrow stroma as well as other mesodermal tissues (59-62). Adding a layer of third party MSCs to the liquid culture system, as proposed by McNiece, Robinson, and Shpall, increased significantly the CD34 cell expansion in vitro (53). In addition, by adding MSCs the authors were able to expand cells without CD34 cell selection, a step associated with significant cell loss in the previous studies summarized above. Outcomes of the resulting clinical trial have been reported (54). The approach was a dUCBT in which one of the cords was ex vivo expanded with MSC, while the other unit was transplanted unmanipulated. Thirty-one high-risk hematologic malignancy patients were included. Expansion increased TNC numbers by a median factor of 12.2 and CD34+ cells by a median factor of 30.1, leading to grafts with median cell dose of $5.8 \times 10^{7} \mathrm{TNC} / \mathrm{kg}$. Importantly, the median number of megakaryocyte and platelet progenitors was also increased in the expanded cord. The median time to neutrophil and platelet engraftment was 15 and 42 days, respectively. Chimerism studies indicated that the expanded unit provided early engraftment while the unmanipulated unit provided most of longterm engraftment, although a minority of patients had evidence of long-term expanded-unit hemopoiesis (although the unmanipulated unit predominated). Some of the challenges in this study included the realization that family derived MSC pose significant logistical and coordination problems, which were alleviated by using an "off the shelf" MSC source. An important question unanswered by this study is whether faster engraftment will lead to less transfusions and shorter hospital stay. This question and others of cost effectiveness will be addressed in an upcoming randomized trial. These results provide the rationale for an ongoing international randomized multicenter study comparing unmanipulated dUCBT versus dUCBT containing one ex vivo expanded unit as described above.

\section{CO-INFUSION OF MSC WITH UMBILICAL CORD STEM CELLS}

To study the effect of MSC and UCB co-infusion in vivo, MacMillan conducted a promising phase I-II study in which parental expanded MSCs were co-infused with UCB in pediatric patients with high-risk leukemia following myeloablative conditioning (63). Among patients receiving MSC/UCB co-infusions, 
median neutrophil and platelet engraftment occurred 19 and 53 days after transplant, respectively. Grade II-IV aGVHD rate was $38 \%$, while there was no cGVHD observed and OS was $75 \%$ at 1 year.

\section{COPPER CHELATION}

Cellular copper concentration modulates differentiation of cord blood hematopoietic stem cells $(64,65)$. Copper chelation has been used to arrest maturation during cord blood expansion, and may lead to expansion of primitive progenitors without differentiation to a less pluripotent cell $(66,67)$. The feasibility of ex vivo expansion using a copper chelator in a liquid ex vivo expansion system was investigated in a phase I/II study that included 10 advanced hematologic malignancy patients. UCB units frozen in two fractions had the smaller fraction cultured for 21 days in media with cytokines. The median CD34+ cell increase was sixfold, resulting in a mean time to neutrophil and platelet engraftment of 30 and 48 days, respectively. Primary graft failure occurred in one patient. Grade II-IV aGVHD occurred in $44 \%$ of cases, while survival after 100 days was $90 \%$ (68). An ongoing multicenter randomized trial is comparing single unit UCBT with or without partial ex vivo expansion through copper chelation.

\section{NOTCH-MEDIATED EXPANSION}

Delaney and Collaborators have investigated a novel strategy of ex vivo expansion based on the knowledge that Notch signaling is involved in hematopoietic stem cell renewal and maintenance (69-73). Mouse transplant models using ex vivo Notch-mediated expansion of selected human umbilical cord CD34+ stem cells have resulted in improved hematopoietic engraftment (74). Ex vivo expansion of CD34+ HSC resulted in a 222-fold expansion following culture for 17-21 days in the presence of fibronectin fragments and immobilized engineered Notch ligand. A phase I clinical trial was conducted in Seattle, in which 10 hematologic malignancy patients with receiving myeloablative conditioning and dUCBT with HLA matched to at least 4/6 HLA loci in each unit. One unit was $100 \%$ ex vivo expanded and the other was not. The median time to neutrophil engraftment was 16 days; grade IIIV aGVHD was $100 \%$. After a mean follow-up of 354 days, survival was $70 \%$.

Since most studies reported so far used a dUCBT or investigated expansion of a fraction of a single unit (Table 4), it is unclear if expansion preserves the long-term engraftment capacity. The expanded unit is outcompeted in dUCBT or fractional models, as discussed above, but it is yet unknown whether this phenomenon represents loss of engraftment-facilitating cells (most expansion platforms deplete lymphocytes) or stem cell exhaustion.

\section{INTRAOSSEOUS TRANSPLANTATION}

A significant proportion of hematopoietic stem cells do not reach the bone marrow niche after intravenous (iv) infusion $(75,76)$. In mouse models, intrabone (ib) injection of hematopoietic stem cells improves engraftment, possibly by bypassing "trapping" in organs such as the lung, liver, and kidney (77-82). Interestingly, ib transplantation has also led to decreased GVHD rates in murine models (83-85).
Hägglund and Colleagues conducted the first human studies of ib transplantation (86). Thirty-four patients were randomized to either iv alone, ib alone, or iv $+\mathrm{ib}$ following myeloablative conditioning. There were no differences in survival, engraftment, or GVHD between groups. Of note, Technetium (Tc-99m) scintigraphy imaging studies demonstrated similar stem cell body distribution in all groups.

Frassoni and Collaborators performed 32 ibUCBT after myeloablative conditioning to treat hematologic malignancies (87). The grafts were matched to at least 4/6 HLA loci and the median TNC dose infused was $2.6 \times 10^{7} \mathrm{c} / \mathrm{kg}$. Median time to neutrophil and platelet engraftment was 23 and 27 days, respectively. There were no instances of grade III-IV aGVHD, and the authors suggested there was a reduced risk of aGVHD with this strategy. Interestingly, a subsequent study performed PET imaging sites of ibUCBT recipients and found that platelet recovery correlated with increased FDG uptake within the area of injection (88).

Studies performed by investigators at the University of Minnesota group were not able to reproduce these promising results. Brunstein et al. published a study of 10 patients who underwent dUCBT following myeloablative conditioning to treat hematologic malignancies (89). One unit underwent ib infusion, whereas the other was injected iv. The trial was closed earlier due to futility given engraftment times similar to historic numbers.

Recently, Carrancio et al. showed that ib co-transplantation of MSC in combination with human CD34+ UCB cells led to improved engraftment in a NOC/SCID mouse model (90). We are now also investigating these intriguing observations, with the hypothesis that human ib $\mathrm{CB}$ transplants can be improved by "priming" with MSC.

Following the preliminary success of many of the above studies, many new trials are enrolling patients. Most new trials have focused on novel methods of UCB engraftment or expansion.

\section{ONGOING AND NEW STUDIES}

Following the preliminary success of many of the above studies, many new trials are enrolling patients. Most new trials have focused on novel methods of UCB engraftment or expansion.

Gamida Cell is sponsoring multicenter studies investigating ex vivo expansion utilizing NiCord (copper chelation). One trial is a dUCBT following myeloablative conditioning: one cord will be $100 \%$ expanded while the other will be unmanipulated. They are also sponsoring a trial evaluating the safety of a single UCBT in which a fraction of the unit is expanded with NiCord (Clinical Trial identifier: NCT01590628, NCT01221857).

The University of Pennsylvania has opened a phase I study where patients undergoing UCBT will have a part of the cord expanded specifically for the generation of $\mathrm{T}$ cells that could be used for adoptive immunotherapy after transplant (Clinical Trial identifier: NCT00891592).

The Fred Hutchinson Cancer Center has opened a randomized phase II trial comparing dUCBT with or without Notch-mediated ex vivo cord expansion (Clinical Trial identifier: NCT01690520). Another phase II study opened at that institution is investigating the infusion of a non-HLA-matched ex vivo expanded cord (i.e., an "off the shelf" cord) combined with either a single or dUCBT 


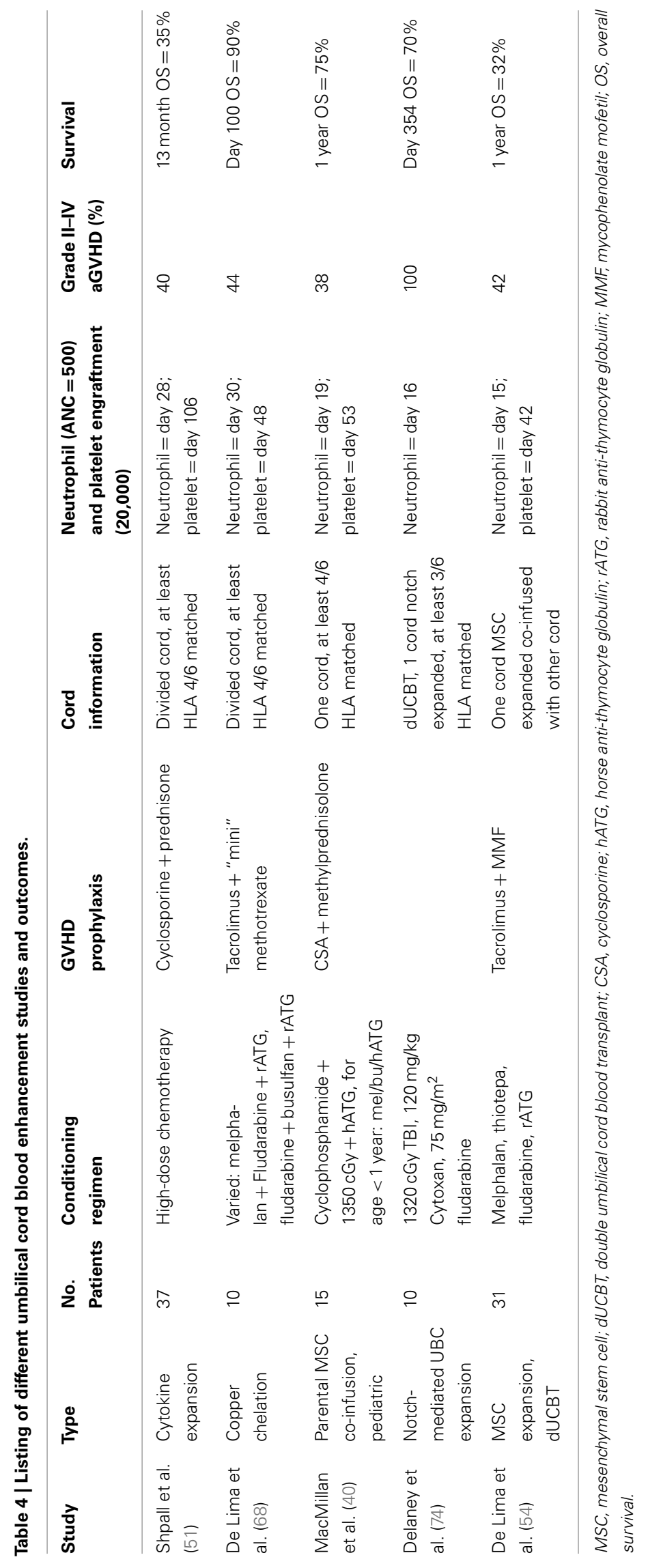


(Clinical Trial identifier: NCT01175785). Both studies focus on reducing engraftment time.

Dana Farber Cancer Institute investigators are exposing UCB grafts to PGE2 with the goal of improving engraftment rates (Clinical Trial identifier: NCT00890500).

The MD Anderson Cancer Center group (P.I. Elizabeth Shpall) and Mesoblast are leading a randomized trial of dUCBT in which one unit is ex vivo expanded using the MSC strategy discussed above, versus controls receiving unmanipulated dUCBT grafts. This trial is also open for accrual at University Hospitals Case Medical Center, Case Western Reserve University, and other centers in the U.S. and Europe (Clinical Trial Identifier: NCT00498316).

Shpall and Collaborators are studying fucosylation as a means of increasing homing and engraftment of UCB. Fucosylation is the process of adding fructose to a molecule. Ex vivo fucosylation of cord blood CD34+ cells has shown to improve engraftment in a NOD/SCID mouse model (91). In this trial, the UCB unit is incubated with a fucosylating enzyme before transplantation. It hypothesized that fucosylation may lead to faster engraftment in humans by changing UCB CD34+ cell ligands (Clinical Trial Identifier: NCT01471067).

\section{REFERENCES}

1. Gluckman E, Broxmeyer HA, Auerbach AD, Friedman HS, Douglas GW, Devergie A, et al. Hematopoietic reconstitution in a patient with Fanconi's anemia by means of umbilical-cord blood from an HLA-matched sibling. $N$ Engl J Med (1989) 321:1174-8. doi:10. 1056/NEJM198910263211707

2. Rubinstein P, Rosenfield RE, Adamson JW, Stevens CE. Stored placental blood for unrelated bone marrow reconstitution. Blood (1993) 81:1679-90.

3. Rubinstein P, Dobrila L, Rosenfield RE, Adamson JW, Migliaccio G, Migliaccio AR, et al. Processing and cryopreservation of placental/umbilical cord blood for unrelated bone marrow reconstitution. Proc Natl Acad Sci U S A (1995) 92:10119-22. doi:10.1073/pnas.92. 22.10119

4. Broxmeyer HE, Hangoc G, Cooper S, Ribeiro RC, Graves V, Yoder M, et al. Growth characteristics and expansion of human umbilical cord blood and estimation of its potential for transplantation in adults. Proc Natl Acad Sci U S A (1992) 89:4109-13. doi:10.1073/pnas.89.9. 4109

5. Barker JN, Byam CE, Kernan NA, Lee SS, Hawke RM, Doshi KA, et al. Availability of cord blood extends allogeneic hematopoietic stem cell transplant access to racial and ethnic minorities. Biol Blood Marrow Transplant (2010) 16(11):1541-8. doi:10.1016/j.bbmt. 2010.08.011
6. Wagner JE, Kernan NA, Steinbuch M, Broxmeyer HE, Gluckman E. Allogeneic sibling umbilicalcord-blood transplantation in children with malignant and nonmalignant disease. Lancet (1995) 346:214-9. doi:10.1016/S01406736(95)91268-1

7. Wagner JE, Rosenthal J, Sweetman R, Shu XO, Davies SM, Ramsay NK, et al. Successful transplantation of HLA-matched and HLA-mismatched umbilical cord blood from unrelated donors: analysis of engraftment and acute graft-versus-host disease. Blood (1996) 88(3):795-802.

8. Barker JN, Davies SM, DeFor T, Ramsay NK, Weisdorf DJ, Wagner JE. Survival after transplantation of unrelated donor umbilical cord blood is comparable to that of human leukocyte antigen-matched unrelated donor bone marrow: results of a matched-pair analysis. Blood (2001) 97(10):2957-61. doi: 10.1182/blood.V97.10.2957

9. Rubinstein P, Carrier C, Scaradavou A, Kurtzberg J, Adamson J, Migliaccio AR, et al. Outcomes among 562 recipients of placental-blood transplants from unrelated donors. $N$ Engl JMed (1997) 339:1565-77. doi: 10.1056/NEJM199811263392201

10. Gluckman E, Rocha V, BoyerChammard A, Locatelli F, Arcese W, Pasquini R, et al. Outcome of cord-blood transplantation from related and unrelated donors. Eurocord transplant group and the European blood and marrow transplantation group. $N$ Engl J Med

\section{CONCLUSION}

Over the last 25 years, UCBT has become a valid source of hematopoietic stem cells, allowing for increased access to hematopoietic stem cell transplantation, particularly in patients without available BMT or PBSC donors. Decreased engraftment rates and kinetics are still important limitations of this hematopoietic stem cell source. UCB engraftment has been the focus of intensive basic and early clinical research and recent progress indicates that several methods will become soon widely available to increase the applicability of this graft type. Future challenges to research in UCBT will include identification of the optimal methods that expedite engraftment and immune reconstitution after transplant and the effect these methods will have in GVHD, disease control, and long-term transplant complications. With the increased development of haploidentical donor transplants, researchers will have the additional charge of performing studies that accurately delineate the role of these two alternative graft sources to allow a rational use of resources in the new exciting reality of widespread availability of graft sources for patients in need of an allogeneic hematopoietic stem cell transplantation.

(1997) 337:373-81. doi:10.1056/ NEJM199708073370602

11. Rocha V, Cornish J, Sievers EL, Filipovich A, Locatelli F, Peters C, et al. Comparison of outcomes of unrelated bone marrow and umbilical cord blood transplants in children with acute leukemia. Blood (2001) 97(10):2962-71. doi: 10.1182/blood.V97.10.2962

12. Eapen M, Rubinstein P, Zhang MJ, Stevens C, Kurtzberg J, Scaradavou A, et al. Outcomes of transplantation of unrelated donor umbilical cord blood and bone marrow in children with acute leukaemia: a comparison study. Lancet (2007) 369(9577):1947-54. doi:10.1016/ S0140-6736(07)60915-5

13. Kurtzberg J, Prasad VK, Carter SL, Wagner JE, Baxter-Lowe LA, Wall D, et al. Results of the cord blood transplantation study (COBLT): clinical outcomes of unrelated donor umbilical cord blood transplantation in pediatric patients with hematologic malignancies. Blood (2008) 112:4318-27. doi:10.1182/ blood-2007-06-098020

14. Wagner JE, Barker JN, DeFor TE, Baker KS, Blazar BR, Eide C, et al. Transplantation of unrelated donor umbilical cord blood in 102 patients with malignant and nonmalignant diseases: influence of CD34 cell dose and HLA disparity on treatment-related mortality and survival. Blood (2002) 100(5):1611-8.

15. Locatelli F, Rocha V, Chastang C, Arcese W, Michel G, Abecasis M, et al. Factors associated with outcome after cord blood transplantation in children with acute leukemia. Eurocord-cord blood transplant group. Blood (1999) 93:3662-71.

16. Gluckman E, Rocha V. Cord blood transplantation for children with acute leukaemia: a Eurocord registry analysis. Blood Cells Mol Dis (2004) 33:271-3.

17. Laughlin MJ, Barker J, Bambach B, Koc ON, Rizzieri DA, Wagner JE, et al. Hematopoietic engraftment and survival in adult recipients of umbilical-cord blood from unrelated donors. $N$ Engl J Med (2001) 344(24):1815-22. doi:10. 1056/NEJM200106143442402

18. Sanz GF, Saavedra S, Planelles D, Senent L, Cervera J, Barragán E, et al. Standardized, unrelated donor cord blood transplantation in adults with hematologic malignancies. Blood (2001) 98:2332-8. doi:10.1182/blood.V98.8.2332

19. Cornetta K, Laughlin M, Carter S, Wall D, Weinthal J, Delaney C, et al. Umbilical cord blood transplantation in adults: results of the prospective cord blood transplantation (COBLT). Biol Blood Marrow Transplant (2005) 11:149-60. doi:10.1016/j.bbmt.2004.11.020

20. Takahashi S, Iseki T, Ooi J, Tomonari A, Takasugi K, Shimohakamada $\mathrm{Y}$, et al. Single-institute comparative analysis of unrelated bone marrow transplantation and cord blood transplantation for adult patients with hematologic malignancies. Blood (2004) 104:3813-20. doi:10.1182/blood2004-03-1001 
21. Ballen KK, Spitzer TR, Yeap BY, McAfee S, Dey BR, Attar E, et al. Double unrelated reduced-intensity umbilical cord blood transplantation in adults. Biol Blood Marrow Transplant (2007) 13(1):82-9. doi: 10.1016/j.bbmt.2006.08.041

22. Hamza NS, Lisgaris M, Yadavalli G, Nadeau L, Fox R, Fu P, et al. Kinetics of myeloid and lymphocyte recovery and infectious complications after unrelated umbilical cord blood versus HLA-matched unrelated donor allogeneic transplantation in adults. $\mathrm{Br} \mathrm{J}$ Haematol (2004) 124:488-98. doi:10.1046/ j.1365-2141.2003.04792.x

23. Rocha V, Labopin M, Sanz G, Arcese W, Schwerdtfeger R, Bosi A, et al. Transplants of umbilical cord blood or bone marrow from unrelated donors in adults with acute leukemia. $N$ Engl J Med (2004) 351:2276-85. doi:10.1056/ NEJMoa041469

24. Eapen M, Rocha V, Sanz G, Scaradavou A, Zhang MJ, Arcese W, et al. Effect of graft source on unrelated donor haemopoietic stem-cell transplantation in adults with acute leukaemia: a retrospective analysis. Lancet Oncol (2010) 11:653-60. doi: 10.1016/S1470-2045(10)70127-3

25. Eapen M, Klein JP, Sanz GF, Spellman S, Ruggeri A, Anasetti C, et al. Effect of donor-recipient HLA matching at HLA A, B, C, and DRB1 on outcomes after umbilical-cord blood transplantation for leukaemia and myelodysplastic syndrome: a retrospective analysis. Lancet Oncol (2011) 12:1214-21. doi:10.1016/ S1470-2045(11)70260-1

26. Slavin S, Nagler A, Naparstek E, Kapelushnik Y, Aker M, Cividalli $\mathrm{G}$, et al. Nonmyeloablative stem cell transplantation and cell therapy as an alternative to conventional bone marrow transplantation with lethal cytoreduction for the treatment of malignant and nonmalignant hematologic diseases. Blood (1998) 91:756-63.

27. Childs R, Clave E, Contentin N, Jayasekera D, Hensel N, Leitman $S$, et al. Engraftment kinetics after nonmyeloablative allogeneic peripheral blood stem cell transplantation: full donor T-cell chimerism precedes alloimmune responses. Blood (1999) 94:3234-41.

28. Sykes M, Preffer F, McAfee S, Saidman SL, Weymouth D, Andrews DM, et al. Mixed lymphohaemopoietic chimerism and graft-versus lymphoma effects after non-myeloablative therapy and
HLA-mismatched bone-marrow transplantation. Lancet (1999) 353:1755-9. doi:10.1016/S01406736(98)11135-2

29. Khouri IF, Keating M, Körbling M, Przepiorka D, Anderlini P, O’Brien $S$, et al. Transplant-lite: induction of graft-versus-malignancy using fludarabine-based nonablative chemotherapy and allogeneic blood progenitor-cell transplantation as treatment for lymphoid malignancies. J Clin Oncol (1998) 16:2817-24.

30. Childs R, Chernoff A, Contentin N, Bahceci E, Schrump D, Leitman S, et al. Regression of metastatic renalcell carcinoma after nonmyeloablative allogeneic peripheral-blood stem-cell transplantation. $N$ Engl $J$ Med (2000) 343:750-8. doi:10. 1056/NEJM200009143431101

31. Giralt S, Thall PF, Khouri I, Wang X, Braunschweig I, Ippolitti $\mathrm{C}$, et al. Melphalan and purine analog-containing preparative regimens: reduced intensity conditioning for patients with hematologic malignancies undergoing allogeneic progenitor cell transplantation. Blood (2001) 97:631-7. doi:10. 1182/blood.V97.3.631

32. McSweeney PA, Niederwieser D, Shizuru JA, Sandmaier BM, Molina AJ, Maloney DG, et al. Hematopoietic cell transplantation in older patients with hematologic malignancies: replacing high-dose cytotoxic therapy with graft-versus tumor effects. Blood (2001) 97:3390-400. doi:10.1182/blood.V97.11.3390

33. Nagler A, Aker M, Or R, Naparstek E, Varadi G, Brautbar C, et al. Low-intensity conditioning is sufficient to ensure engraftment in matched unrelated bone marrow transplantation. Exp Hematol (2001) 29:362-70. doi:10.1016/ S0301-472X(00)00655-X

34. Chakraverty R, Peggs K, Chopra R, Milligan DW, Kottaridis PD, Verfuerth $S$, et al. Limiting transplantation-related mortality following unrelated donor stem cell transplantation by using a nonmyeloablative conditioning regimen. Blood (2002) 99:1071-8. doi:10.1182/blood.V99.3.1071

35. Barker JN, Weisdorf DJ, DeFor TE, Blazar BR, Miller JS, Wagner JE. Rapid and complete donor chimerism in adult recipients of unrelated donor umbilical cord blood transplantation after reduced-intensity conditioning. Blood (2003) 102:1915-9. doi:10.1182/blood-2002-11-3337
36. Brunstein CG, Eapen M, Ahn KW, Appelbaum FR, Ballen KK, Champlin RE, et al. Reducedintensity conditioning transplantation in acute leukemia: the effect of source of unrelated donor stem cells on outcomes. Blood (2012) 119(23):5591-8. doi: 10.1182/blood-2011-12-400630

37. Barker JN, Weisdorf DJ, Wagner JE. Creation of a double chimera after the transplantation of umbilicalcord blood from two partially matched unrelated donors. $N$ Eng J Med (2001) 344(24):1870-1. doi: 10.1056/NEJM200106143442417

38. De Lima M, St John LS, Wieder ED Lee MS, McMannis J, Karandish S, et al. Double-chimaerism after transplantation of two human leucocyte antigen mismatched, unrelated cord blood units. $\mathrm{Br} J$ Haematol (2002) 119(3):773-6. doi:10.1046/j. 1365-2141.2002.03893.x

39. Barker JN, Weisdorf DJ, DeFor TE, Blazar BR, McGlave PB, Miller JS, et al. Transplantation of 2 partially HLA-matched umbilical cord blood units to enhance engraftment in adults with hematologic malignancy. Blood (2005) 105:1343-7.

40. MacMillan ML, Weisdorf DJ, Brunstein CG, Cao Q, DeFor TE, Verneris MR, et al. Acute graftversus-host disease after unrelated donor umbilical cord blood transplantation: analysis of risk factors. Blood (2009) 113:2410-5. doi:10. 1182/blood-2008-07-163238

41. Brunstein CG, Barker JN, Weisdorf DJ, DeFor TE, Miller JS, Blazar BR, et al. Umbilical cord blood transplantation after nonmyeloablative conditioning: impact on transplantation outcomes in 110 adults with hematologic disease. Blood (2007) 110(8):3064-70. doi: 10.1182/blood-2007-04-067215

42. Kindwall-Keller TL, Hegerfeldt Y, Meyerson HJ, Margevicius S, Fu P, van Heeckeren W, et al. Prospective study of single vs. two unit umbilical cord blood transplantation following reduced intensity conditioning in adults with hematologic malignancies. Bone Marrow Transplant (2012) 47(7):924-33. doi:10. 1038/bmt.2011.195

43. Wagner JE, Eapen M, Carter SL, Haut PR, Peres E, Schultz KR, et al. No Survival Advantage after Double Umbilical Cord Blood (UCB) Compared to Single UCB Transplant in Children with Hematological Malignancy: Results of the Blood and Marrow Transplant Clinical Trials Network (BMT CTN 0501) Randomized Trial [Presentation]. ASH (2012).
44. Brunstein CG, Gutman JA, Weisdorf DJ, Woolfrey AE, Defor TE, Gooley TA, et al. Allogeneic hematopoietic cell transplantation for hematologic malignancy: relative risks and benefits of double umbilical cord blood. Blood (2010) 116:4693-9. doi:10. 1182/blood-2010-05-285304

45. Avery S, Shi W, Lubin M, Gonzales AM, Heller G, Castro-Malaspina $\mathrm{H}$, et al. Influence of infused cell dose and HLA-match on engraftment after double-unit cord blood allografts. Blood (2011) 117(12):3277-85. doi:10.1182/ blood-2010-08-300491

46. Arcese W, Rocha V, Labopin M, Sanz G, Iori AP, de Lima M, et al. Unrelated cord blood transplants in adults with hematologic malignancies. Haematologica (2006) 91:223-30.

47. Barker JN, Scaradavou A, Stevens CE. Combined effect of total nucleated cell dose and HLA match on transplant outcome in 1061 cord blood recipients with hematological malignancies. Blood (2010) 115(9):1843-9. doi:10.1182/blood2009-07-231068

48. Barker JN, Byam C, Scaradavou A. How I treat: the selection and acquisition of unrelated cord blood grafts. Blood (2011) 117(8):2332-9. doi:10.1182/blood-2010-04280966

49. Fernández MN, Regidor C, Cabrera R, García-Marco JA, Forés R, Sanjuán I, et al. Unrelated umbilical cord blood transplants in adults: early recovery of neutrophils by supportive co-transplantation of a low number of highly purified peripheral blood CD34+ cells from an HLA-haploidentical donor. Exp Hematol (2003) 31(6):535-44. doi: 10.1016/S0301-472X(03)00067-5

50. Liu H, Rich ES, Godley L, Odenike O, Joseph L, Marino S, et al. Reduced-intensity conditioning with combined haploidentical and cord blood transplantation results in rapid engraftment, low GVHD, and durable remissions. Blood (2011) 118:6438-45. doi:10.1182/ blood-2011-08-372508

51. Shpall EJ, Quinones R, Giller $\mathrm{R}$, Zeng $\mathrm{C}$, Baron $\mathrm{AE}$, Jones $\mathrm{RB}$, et al. Transplantation of exvivo expanded cord blood. Biol Blood Marrow Transplant (2002) 8:368-76. doi:10.1053/bbmt.2002. v8.pm12171483

52. de Lima M, McMannis J, Komaduri K, Worth L, Karandish S, Jones $\mathrm{R}$, et al. Randomized study of double cord blood transplantation (CBT)with versus without ex vivo 
expansion (EXP). Presented at the 49th Annual Meeting of the American Society of Hematology. Atlanta (2007). [Abstract].

53. Robinson SN, Ng J, Niu T, Yang H, McMannis JD, Karandish S, et al. Superior ex vivo cord blood expansion following co-culture with bone marrow derived mesenchymal stem cells. Bone Marrow Transplant (2006) 37:359-66. doi:10.1038/sj. bmt.1705258

54. de Lima M, McNiece I, Robinson SN, Munsell M, Eapen M, Horowitz $M$, et al. Cord-blood engraftment with ex vivo mesenchymalcell coculture. $N$ Eng $J$ Med (2012) 367(24):2305-15. doi:10. 1056/NEJMoa1207285

55. Verfaillie CM. Direct contact between human primitive hematopoietic progenitors and bone marrow stroma is not required for long-term in vitro hematopoiesis. Blood (1992) 79:2821-6.

56. Choudhury C. Role of the microenvironment on hematopoiesis. I. Stem cell differentiation into granulocytic and megakaryocytic cell lineage. J Lab Clin Med (1989) 114:378-81.

57. Harigaya K, Handa H. Generation of functional clonal cell lines from human bone marrow stroma. Proc Natl Acad Sci U S A (1985) 82:3477-80. doi:10.1073/ pnas.82.10.3477

58. Gordon MY, Clarke D, Atkinson J, Greaves MF. Hemopoietic progenitor cell binding to the stromal microenvironment in vitro. Exp Hematol (1990) 18:837-42.

59. Ashton BA, Allen TD, Howlett CR, Eaglesom CC, Hattori A, Owen M. Formation of bone and cartilage by marrow stromal cells in diffusion chambers in vivo. Clin Orthop Relat Res (1980) 151:294-307.

60. Beresford JN. Osteogenic stem cells and the stromal system of bone and marrow. Clin Orthop Relat Res (1989) 240:270-80.

61. Bab I, Passi-Even L, Gazit D, Sekeles E, Ashton BA, Peylan-Ramu N, et al. Osteogenesis in in vivo diffusion chamber cultures of human marrow cells. Bone Miner (1988) 4:373-86.

62. Cheng L, Mbalaviele G, Liu X. Human mesenchymal stem cell support proliferation and multilineage differentiation of human hematopoietic stem cells. Blood (1998) 92:57a.

63. MacMillan ML, Blazar BR, DeFor TE, Wagner JE. Transplantation of ex-vivo culture-expanded parental haploidentical mesenchymal stem cells to promote engraftment in pediatric recipients of unrelated donor umbilical cord blood: results of a phase I-II clinical trial. Bone Marrow Transplant (2009) 43:447-54. doi:10.1038/bmt.2008. 348

64. Peled T, Landau E, Prus E, Treves AJ, Nagler A, Fibach E. Cellular copper content modulates differentiation and self-renewal in cultures of cord blood-derived CD34+ cells. $\mathrm{Br}$ J Haematol (2002) 116:655-61. doi: 10.1046/j.0007-1048.2001.03316.x

65. Peled T, Glukhman E, Hasson $\mathrm{N}$, Adi S, Assor $\mathrm{H}$, Yudin $\mathrm{D}$, et al. Chelatable cellular copper modulates differentiation and self-renewal of cord blood-derived hematopoietic progenitor cells. Exp Hematol (2005) 33:1092-100. doi: 10.1016/j.exphem.2005.06.015

66. Peled T, Mandel J, Goudsmid RN, Landor C, Hasson N, Harati D, et al. Pre-clinical development of cord blood-derived progenitor cell graft expanded ex vivo with cytokines and the polyamine copper chelator tetraethylenepentamine. Cytotherapy (2004) 6:344-55. doi:10.1080/ 14653240410004916

67. Peled T, Landau E, Mandel J, Glukhman E, Goudsmid NR, Nagler A, et al. Linear polyamine copper chelator tetraethylenepentamine augments long-term ex vivo expansion of cord blood-derived CD34+ cells and increases their engraftment potential in NOD/SCID mice. Exp Hematol (2004) 32:547-55. doi:10.1016/j.exphem.2004.03.002

68. de Lima M, McMannis J, Gee A, Komanduri K, Couriel D, Andersson BS, et al. Transplantation of ex vivo expanded cord blood cells using the copper chelator tetraethylenepentamine: a phase I/II clinical trial. Bone Marrow Transplant (2008) 41:771-8. doi:10.1038/ sj.bmt.1705979

69. Kojika S, Griffin JD. Notch receptors and hematopoiesis. Exp Hematol (2001) 29(9):1041-52. doi:10. 1016/S0301-472X(01)00676-2

70. Milner LA, Kopan R, Martin DI, Bernstein ID. A. Blood (1994) 83(8):2057-62.

71. Karanu FN, Murdoch B, Gallacher L, Wu DM, Koremoto M, Sakano $\mathrm{S}$, et al. The notch ligand jagged1 represents a novel growth factor of human hematopoietic stem cells. J Exp Med (2000) 192(9):1365-72. doi:10.1084/jem.192.9.1365

72. Karanu FN, Murdoch B, Miyabayashi T, Ohno M, Koremoto M, Gallacher L, et al. Human homologues of Delta- 1 and Delta-4 function as mitogenic regulators of primitive human hematopoietic cells. Blood (2001) 97(7):1960-7. doi:10.1182/blood.V97.7.1960

73. Varnum-Finney B, Xu L, BrashemStein C, Nourigat C, Flowers D, Bakkour S, et al. Pluripotent cytokine-dependent, hematopoietic stem cells are immortalized by constitutive Notch1 signaling. Nat Med (2000) 6(11):1278-81. doi:10.1038/ 81390

74. Delaney C, Heimfeld S, BrashemStein C, Voorhies H, Manger RL, Bernstein ID. Notch mediated expansion of human cord blood progenitor cells capable of rapid myeloid reconstitution. Nat $\mathrm{Med}$ (2010) 16:232-6. doi:10.1038/nm. 2080

75. vanHennik $\mathrm{PB}$, de Koning $\mathrm{AE}$ Ploemacher RE. Seeding efficiency of primitive human hematopoietic cells in nonobese diabetic/severe combined immune deficiency mice: implications for stem cell frequency assessment. Blood (1999) 94:3055-61.

76. Cui J, Wahl RL, Shen T, Fisher SJ, Recker E, Ginsburg D, et al. Bone marrow cell trafficking following intravenous administration. Br J Haematol (1999) 107:895-902. doi:10.1046/j.13652141.1999.01779.x

77. Kushida $T$, Inaba $M$, Hisha $H$, Ichioka N, Esumi T, Ogawa R, et al. Intra-bone marrow injection of allogeneic bone marrow cells: a powerful new strategy for treatment of intractable autoimmune diseases in MRL/lpr mice. Blood (2001) 97:3292-9. doi:10.1182/blood.V97. 10.3292

78. Zhong JF, Zhan Y, Anderson WF, Zhao Y. Murine hematopoietic stem cell distribution and proliferation in ablated and nonablated bone marrow transplantation. Blood (2002) 100:3521-6. doi:10. 1182/blood-2002-04-1256

79. Mazurier F, Doedens M, Gan OI, Dick JE. Rapid myeloerythroid repopulation after intrafemoral transplantation of NOD-SCID mice reveals a new class of human stem cells. Nat Med (2003) 9:959-63. doi:10.1038/nm886

80. Yahata T, Ando K, Sato T, Miyatake $H$, Nakamura $Y$, Muguruma $\mathrm{Y}$, et al. A highly sensitive strategy for SCID repopulating cell assay by direct injection of primitive human hematopoietic cells into NOD/SCID mice bone marrow. Blood (2003) 101:2905-13. doi:10. 1182/blood-2002-07-1995
81. Wang J, Kimura T, Asada R, Harada S, Yokota S, Kawamoto $\mathrm{Y}$, et al. SCID-repopulating cell activity of human cord blood derived CD34- cells assured by intra-bone marrow injection. Blood (2003) 101:2924-31. doi:10.1182/ blood-2002-09-2782

82. Castello $\mathrm{S}$, Podestà $\mathrm{M}$, Menditto VG, Ibatici A, Pitto A, Figari O, et al. Intra-bone marrow injection of bone marrow and cord blood cells: an alternative way of transplantation associated with a higher seeding efficiency. Exp Hematol (2004) 32:782-7. doi:10. 1016/j.exphem.2004.05.026

83. Nakamura K, Inaba M, Sugiura $\mathrm{K}$, Yoshimura $\mathrm{T}$, Kwon $\mathrm{AH}$, Kamiyama Y, et al. Enhancement of allogeneic hematopoietic stem cell engraftment and prevention of GVHD by intra-bone marrow bone marrow transplantation plus donor lymphocyte infusion. Stem Cells (2004) 22:125-34. doi:10. 1634/stemcells.22-2-125

84. Nishida T, Hosaka N, Takaki T, Miyake $\mathrm{T}$, Cui $\mathrm{W}$, Inaba $\mathrm{M}$, et al. Allogeneic intra-BM-BMT plus adult thymus transplantation from same donor has benefits for longterm survival even after sublethal irradiation or low-dose BM cell injection. Bone Marrow Transplant (2009) 43:829-37. doi:10.1038/bmt. 2008.396

85. Miyake T, Hosaka N, Cui W, Nishida $\mathrm{T}$, Takaki $\mathrm{T}$, Inaba $\mathrm{M}$, et al. Adult thymus transplantation with allogeneic intra-bone marrow-bone marrow transplantation from same donor induces high thymopoiesis, mild graft-versushost reaction and strong graftversus-tumour effects. Immunology (2009) 126:552-64. doi:10.1111/j. 1365-2567.2008.02920.x

86. Hägglund $\mathrm{H}, \quad$ Ringdén $\mathrm{O}$ Agren B, Wennberg L, Remberger $M$, Rundquist $L$, et al. Intraosseous compared to intravenous infusion of allogeneic bone marrow. Bone Marrow Transplant (1998) 21:331-5. doi:10.1038/sj.bmt.1701116

87. Frassoni F, Gualandi F, Podesta M, Raiola AM, Ibatici A, Piaggio G, et al. Direct intrabone transplant of unrelated cord-blood cells in acute leukaemia: a phase I/II study. Lancet Oncol (2008) 9:831-9. doi:10.1016/S1470-2045(08) 70180-3

88. Marini C, Podestà M, Massollo M, Capitanio S, Fiz F, Morbelli $S$, et al. Intrabone transplant of cord blood stem cells establishes 
a local engraftment store: a functional PET/FDG study. J Biomed Biotechnol (2012) 2012:767369. doi: $10.1155 / 2012 / 767369$

89. Brunstein CG, Barker JN, Weisdorf DJ, Defor TE, McKenna D, Chong SY, et al. Intra-BM injection to enhance engraftment after myeloablative umbilical cord blood transplantation with two partially HLA-matched units. Bone Marrow Transplant (2009) 43:935-40. doi: 10.1038/bmt.2008.417

90. Carrancio S, Romo C, Ramos T, Lopez-Holgado N, Muntion
S, Prins HJ, et al. Effects of MSC-co-administration and route of delivery on cord blood hematopoietic stem cell engraftment. Cell Transplant (2013) 22(7): 1171-83. doi:10.3727/ 096368912X657431

91. Robinson SN, Simmons PJ, Thomas MW, Brouard N, Javni JA, Trilok S, et al. Ex vivo fucosylation improves human cord blood engraftment in NOD-SCID IL-2R $\gamma$ (null) mice. Exp Hematol (2012) 40(6):445-56. doi:10.1016/j. exphem.2012.01.015
Conflict of Interest Statement: The authors declare that the research was conducted in the absence of any commercial or financial relationships that could be construed as a potential conflict of interest.

Received: 24 May 2013; paper pending published: 12 July 2013; accepted: 29 August 2013; published online: 17 September 2013.

Citation: Metheny L, Caimi $P$ and de Lima M (2013) Cord blood transplantation: can we make it better? Front. Oncol. 3:238. doi: 10.3389/fonc.2013.00238
This article was submitted to Hematology Oncology, a section of the journal Frontiers in Oncology.

Copyright (C) 2013 Metheny, Caimi and de Lima. This is an open-access article distributed under the terms of the Creative Commons Attribution License (CC $B Y)$. The use, distribution or reproduction in other forums is permitted, provided the original author(s) or licensor are credited and that the original publication in this journal is cited, in accordance with accepted academic practice. No use, distribution or reproduction is permitted which does not comply with these terms. 